\title{
Efficacy and Fate of Atrazine and Simazine in Doveweed (Murdannia nudiflora)
}

\author{
Jialin Yu and Patrick E. McCullough*
}

\begin{abstract}
Doveweed is a summer annual that is difficult to control in turfgrass. Photosystem II inhibitors have the potential to control doveweed, but research is limited on the efficacy of these herbicides. The objectives of this research were to evaluate (1) the differential tolerance levels of doveweed to atrazine and simazine, (2) the influence of application placement and rate on herbicide efficacy, and (3) uptake and metabolism of these herbicides in doveweed. In greenhouse experiments, the time required to injure doveweed $50 \%$ was three to five times faster for atrazine than simazine. Simazine soil or foliar + soil application reduced doveweed biomass $77 \%$ from the nontreated, but foliar-only treatments reduced biomass $51 \%$. Application placements for atrazine equally reduced shoot biomass $96 \%$ from the nontreated. In a dose-response experiment, atrazine and simazine required $\leq 1.8 \mathrm{~kg}$ $\mathrm{ha}^{-1}$ and $\geq 5.1 \mathrm{~kg} \mathrm{ha}^{-1}$ to injure doveweed $50 \%$ from 8 to $16 \mathrm{~d}$ after treatment (DAT), respectively. Doveweed required $79 \%$ less atrazine to reduce biomass $50 \%$ from the nontreated compared with simazine. In laboratory experiments, doveweed had similar root absorption levels of ${ }^{14} \mathrm{C}$-atrazine and ${ }^{14} \mathrm{C}$-simazine. Metabolism of both herbicides linearly increased from 1 to 7 DAT, but parent herbicide levels averaged 39 and $25 \%$ of the extracted radioactivity from ${ }^{14} \mathrm{C}$-atrazine and ${ }^{14} \mathrm{C}$ simazine, respectively. Doveweed metabolized ${ }^{14} \mathrm{C}$-simazine to three major metabolites, including hydroxysimazine, that each ranged from 24 to $29 \%$ of the extracted radioactivity. Hydroxyatrazine was the only major metabolite $\left(>10 \%\right.$ of total ${ }^{14} \mathrm{C}$ extracted $)$ of ${ }^{14} \mathrm{C}$-atrazine. Overall, doveweed has slower metabolism of atrazine compared with simazine and is the basis for differential tolerance levels to these herbicides.
\end{abstract}

Nomenclature: Atrazine, simazine, doveweed, Murdannia nudiflora (L.) Brenan.

Key words: Selectivity, triazine, turfgrass, uptake.

Doveweed is a problematic summer annual weed in turfgrass in the southern United States. It has light green color and coarse leaf texture that reduce turfgrass quality by contrasting with the color and texture of desirable turfgrass. Doveweed is a prolific seed producer, and its stems readily root upon contact of a node with moist soils (Atkinson 2014). Peak germination of doveweed occurs when soil temperatures reach $\sim 28 \mathrm{C}$ (Wilson et al. 2006). This establishment timing is later than most annual weeds that are targeted for PRE control with herbicides in spring. This may explain why researchers have reported erratic levels of PRE doveweed control from oxadiazon and dinitroaniline herbicides (Chauhan and Abugho 2013; Walker et al. 2010). Indaziflam is a cellulose biosynthesis inhibitor with efficacy for PRE doveweed control. Turf managers typically use indaziflam in early spring for controlling annual grassy weeds (Anonymous 2010a). However, PRE doveweed control is usually achieved for a finite period

\footnotetext{
DOI: 10.1614/WS-D-15-00180.1

* Postdoctoral Researcher and Associate Professor, Department of Crop and Soil Sciences, University of Georgia, Griffin, GA 30223. Corresponding author's Email:pmccull@uga.edu
}

of time, after which point control is lessened. Due to doveweed's continuous germination pattern throughout the growing season, POST herbicides in sequential programs are often required for longterm control.

Synthetic auxin herbicides, such as $2,4-\mathrm{D}$, in combination with other herbicides may effectively control doveweed in turfgrass. A single application of synthetic auxin herbicides including 2,4-D, methylchlorophenoxypropionic acid (MCPP), and dicamba with either carfentrazone or sulfentrazone provided $<50 \%$ control of doveweed at $6 \mathrm{wk}$ after treatment, whereas a sequential application improved control from single application to between 60 and 81\% (Atkinson 2014). Sequential applications of these herbicides that are required to control doveweed increase injury potential of sensitive turfgrasses like centipedegrass [Eremochloa ophiuroides (Munro) Hack.] and St. Augustinegrass [Stenotaphrum secundatum (Waltz.) Kuntze] (Anonymous 2008, 2010b; Johnson 1973). Sulfonylureas, such as metsulfuron-methyl, alone or in mixtures with other herbicides, have the potential to suppress doveweed in turfgrass. Field experiments conducted in Georgia determined that the combination of thiencarbazone, foramsulfuron, and halosulfuron 
provided $80 \%$ control of doveweed after $3 \mathrm{wk}$, but control declined to $<60 \%$ by 7 wk after treatment (P McCullough, personal observation).

Herbicide foliar uptake is related to leaf properties such as cuticle thickness, epicuticular waxes, and stomata numbers (Chachalis et al. 2001; Sanyal et al. 2006; Wanamarta and Penner 1989). In previous research, efficacy of POST herbicides for controlling doveweed, and related species has been associated with hydrophobicity and thickness of the leaf cuticle (Atkinson 2014; Monquero et al. 2004). In laboratory experiments with ${ }^{14} \mathrm{C}$-glyphosate, Atkinson (2014) reported that 92 and $72 \%$ of the applied herbicide was adsorbed to doveweed leaves with intact and removed cuticles at $72 \mathrm{~h}$ after treatment, respectively. It was also noted that glyphosate from 90 to $710 \mathrm{~g}$ ae $\mathrm{ha}^{-1}$ reduced doveweed shoot mass $<40 \%$ from the nontreated. Thus, limited foliar uptake of POST herbicides in doveweed may reduce the potential for effective control in turfgrass systems.

Atrazine and simazine are Photosystem II (PS II) inhibitors with significant soil activity on susceptible species (Orwick et al. 1976; Price and Balke 1982; Thompson and Slife 1969). Triazine herbicides are widely used in warm-season turfgrasses for controlling broadleaf weeds and species related to doveweed in other cropping systems, such as Asiatic dayflower (Commelina communis L.) (Johnson 1973, 1979; Ulloa and Owen 2009). Atrazine will provide effective control of doveweed in warmseason turfgrasses, but sequential treatments are needed for best results (J Yu, personal observation). The response of doveweed to atrazine or simazine has not been reported in scientific literature.

Doveweed has prolific growth in summer, and multiple herbicide applications are often needed for control. Although several sulfonylurea and synthetic auxin herbicides control doveweed, the potential to rotate mechanisms of action may be critical for resistance management and maximizing efficacy of control programs. The use of PS II inhibitors for doveweed control may be needed for sequential applications in warm-season turfgrasses, especially if practitioners have applied the maximum annual use rates of other herbicides. Atrazine and simazine have received limited investigation for doveweed control, and further research is needed on the efficacy and fate of these herbicides in this species. The objectives of this research were to evaluate (1) the differential tolerance levels of doveweed to atrazine and simazine, (2) the influence of application placement and rate on herbicide efficacy, and (3) uptake and metabolism of these herbicides in doveweed.

\section{Materials and Methods}

Plant Material. Doveweed was collected in August 2013 from a common bermudagrass [Cynodon dactylon (L.) Pers.] lawn in Valdosta, GA. Roots were rinsed free of soil, and plants were grown individually in 3.8-cm-diam and 20-cm-depth pots filled with sand : peat moss $(85: 15, \mathrm{v} / \mathrm{v})$. Pots were placed in a greenhouse set for 32/25 C (day/ night) in Griffin, GA. Irrigation was applied as needed to prevent wilting, and pots were fertigated weekly (MacroN 28-7-14 Sprayable Fertilizer, LESCO Inc., Cleveland, OH).

\section{Application Placement of Atrazine and Simazine.} The influence of application placement on the efficacy of atrazine and simazine for doveweed control was evaluated in greenhouse experiments. Individual plants were transplanted to pots with 79$\mathrm{cm}^{2}$ surface areas and $10-\mathrm{cm}$ depths. Soil was the aforementioned sand: peat moss. Plants were irrigated as needed and fertilized weekly. Plants were grown in the greenhouse for $2 \mathrm{wk}$ and allowed to develop three to five tillers before treatments.

Treatments were the factorial combination of two herbicides and three application placements. Atrazine (Aatrex 4L, Syngenta Crop Protection, Greensboro, NC 27409) and simazine (Simazine 4L, Drexel Chemical Co., Memphis, TN 38113) were applied at $1.12 \mathrm{~kg} \mathrm{ha}^{-1}$ in three placements: foliaronly, soil-only, or foliar + soil. A nontreated check was included. Foliar-only and foliar + soil treatments were applied with a $\mathrm{CO}_{2}$-pressured sprayer calibrated to deliver $374 \mathrm{~L} \mathrm{ha}^{-1}$ with a single $9504 \mathrm{E}$ flat-fan nozzle (TeeJet Spraying Systems Co., Roswell, GA 30075). Aluminum foil was placed at the soil surface for foliar-only treatments and removed at $1 \mathrm{~h}$ after treatment. Soil-only treatments were applied with a pipette that delivered a $1.12 \mathrm{~kg}$ ai ha ${ }^{-1}$ surface application rate in $10 \mathrm{ml}$ of tap water. Plants were not irrigated for $24 \mathrm{~h}$ but received irrigation thereafter as needed to prevent soil moisture deficiencies. Injury was visually evaluated every $2 \mathrm{~d}$ on a percent scale from 0 (no injury) to 100 (complete desiccation). Aboveground biomass was harvested at $16 \mathrm{~d}$ after treatment (DAT), oven-dried at $60 \mathrm{C}$ for $72 \mathrm{~h}$, and then weighted. Shoot biomass data were converted to percent reductions from the nontreated by replication. 
Application Rates of Atrazine and Simazine. Doveweed was grown in the aforementioned pots (3.8-cm diam by $20-\mathrm{cm}$ depth) for dose-response experiments. Doveweed injury was evaluated from 10 rates of atrazine and simazine: $0.035,0.07,0.14$, $0.28,0.56,1.12,2.24,4.48,8.96$, and $17.92 \mathrm{~kg}$ ai $\mathrm{ha}^{-1}$. A nontreated check was included. Herbicides were applied in a spray chamber calibrated to deliver $187 \mathrm{~L} \mathrm{ha}^{-1}$ with a single $8002 \mathrm{E}$ flat-fan nozzle (TeeJet). Injury was visually estimated on a percent scale from 0 (no injury) to 100 (complete desiccation). Aboveground biomass was harvested at $16 \mathrm{DAT}$, oven-dried at $60 \mathrm{C}$ for $72 \mathrm{~h}$, and then weighted. Shoot biomass data was converted to percent reductions from the nontreated by replication.

Laboratory Experiments. Experiments were conducted in Griffin, GA, using a modified methodology for evaluating ${ }^{14} \mathrm{C}$-atrazine metabolism in soybean [Glycine max (L.) Merr.] by Graham and Buchholtz (1968). Doveweed was established from the transplanted tillers as previously described. Plants were removed from the pots, and soil was rinsed from roots. Plants were then grown hydroponically in a 6-L plastic tank filled with halfstrength Hoagland solution (Hoagland and Arnon 1950). The tank was wrapped in aluminum foil, and roots were suspended in solution by placement through holes drilled in the lid. An aquarium pump (Shkerry Aqua ${ }^{\circledR}$, Shanghai Uni-Aqua Co. Ltd., Chang Shou Road, Shanghai 200042, China) was used to provide oxygen to the solution. The tank was placed in a growth chamber (Percival Scientific Inc., 505 Research Drive, Perry, IA 50220) set for $32 / 25 \mathrm{C}$ (day/night) with $12 \mathrm{~h}$ photoperiods of 350 $\mu \mathrm{mol} \mathrm{m}{ }^{-2} \mathrm{~s}^{-1}$

Plants were acclimated to hydroponic culture for 7 $\mathrm{d}$ in the growth chamber. The plants were then placed individually into 5-ml tubes containing $100 \mu \mathrm{l}$ of half-strength Hoagland solution spiked with 6.7 $\mathrm{kBq}$ of ${ }^{14} \mathrm{C}$-atrazine (ring-labeled, specific activity: $160 \mathrm{mCi} / \mathrm{mmol}$, 98\% chemical purity) or ${ }^{14} \mathrm{C}$ simazine (ring-labeled, specific activity: $50 \mathrm{mCi} /$ mmol, 99\% chemical purity). Formulated herbicide was added to the treatment solutions at $1 \mathrm{mM}$. Roots were submerged in the solution by placing cotton balls around the base of shoots, and tubes were covered. After $4 \mathrm{~h}, 2 \mathrm{ml}$ of tap water was added to vials to reduce moisture stress. Plants were then removed from solution 1 DAT and placed in the aforementioned tank with herbicide-free, halfstrength Hoagland solution. For metabolism analysis, plants were harvested at 1,3 , or 7 DAT. Roots were blotted on paper towels and separated from shoots with shears. Plants harvested for metabolism extractions at 1 DAT were not returned to the hydroponic tank. Samples were stored at $-20 \mathrm{C}$ for $<14 \mathrm{~d}$ before metabolism extractions.

Plants (roots + shoots) were minced and placed in a 50-ml plastic centrifuge tube. Samples were then ground with a tissue homogenizer in $20 \mathrm{ml}$ of methanol and placed in a sonication bath (CPXH8800, Branson Ultrasonics, Danbury, CT 06810) for $2 \mathrm{~h}$. Vials were then centrifuged (Sorvall ST, Thermo Scientific Inc., Waltham, MA 02454) for $5 \mathrm{~min}$ at $5,000 \times g$, and the supernatant was transferred to new vials. This procedure was repeated, and the supernatant was combined. A 4$\mathrm{ml}$ aliquot was sampled from supernatant, and radioactivity was quantified with liquid scintillation spectroscopy (Beckman LS 6500 ${ }^{\circledR}$, Beckman Coulter Inc., Fall River, MA 02720).

The supernatant of all samples was then transferred to new vials and evaporated in a forced-air hood. Samples were then resuspended in $30 \mu \mathrm{l}$ of methanol and spotted on 20 by $20-\mathrm{cm}$ thin-layer chromatography (TLC) plates. The plates were developed to 16 $\mathrm{cm}$ in a glass chamber using ethyl acetate : dichloromethane : acetic acid at 2:16:0.4 (v/v/v) for atrazine and $20: 70: 2$ for simazine. The plates were air-dried, and metabolites were detected with a radiochromatogram scanner (BioScan System 200 Imaging Scanner, Bioscan, 4590 MacArthur Boulevard NW, Washington, DC 20007) connected to a computer equipped with Laura Chromatography Data Collection and Analysis Software ${ }^{\circledR}$ (LabLogic System Inc., 1040 E Brandon Boulevard, Brandon, FL 33511). Stock solutions of radiolabeled atrazine and simazine were developed on TLC plates to identify the retention factor $\left(\mathrm{R}_{\mathrm{f}}\right)$ of the parent herbicides. Hydroxyatrazine ( $99 \%$ chemical purity, Chem Service Inc., West Chester, PA 19381) and hydroxysimazine $(99 \%$ chemical purity, Chem Service) were dissolved in methanol and spotted on TLC plates, and the $\mathrm{R}_{\mathrm{f}}$ was identified with a fluorescence indicator.

Experimental Design and Data Analysis. The designs for greenhouse experiments were a randomized complete block with four replications. Blocks were used to account for potential variability of greenhouse location on plant responses to herbicides. The design in the laboratory experiment was completely randomized with four replications. All experiments were repeated once over time.

Data were subjected to ANOVA with the General Linear Model Procedure in SAS (SAS 9.2, SAS 
Institute Inc., Cary, NC 27513). Means were separated with Fisher's protected LSD test at $\alpha=$ 0.05. Orthogonal polynomial contrasts were used to describe the relationship of plant metabolism over time. The Sigmoid Function of Nonlinear Regression Procedure was used in SAS to determine the time required to injure doveweed $50 \%$ from application placement treatments with the following equation

$$
y-a /\left[1+(x / b)^{c}\right]
$$

where $y$ is injury, $x$ is DAT, $a$ is the asymptote, $b$ is the inflection point, and $c$ is the slope. Estimates of days required to reach $50 \%$ injury $\left(T_{50}\right)$ were calculated using 95\% confidence intervals. The application rate required to injure doveweed 50\% $\left(I_{50}\right)$ or reduce biomass $50 \%\left(\mathrm{SR}_{50}\right)$ were determined from the following equation:

$$
y=a[1-\exp (-b x)]
$$

where $y$ is injury or shoot biomass reduction, $a$ is the asymptote, $b$ is the slope, and $x$ is herbicide rate $(\mathrm{kg}$ $\left.\mathrm{ha}^{-1}\right)$. Growth function models were chosen for regression analysis that described the relationship of plant responses with time or herbicide rate. The $95 \%$ confidence limits of the estimated $T_{50}, I_{50}$, and $\mathrm{SR}_{50}$ values were determined in SigmaPlot (v.11.2, Systat Software Inc., San Jose, CA). Experiment by treatment interactions were not detected; thus, results were pooled over experimental runs.

\section{Results and Discussion}

Greenhouse Experiments. Herbicide by placement interactions were detected for doveweed injury and biomass; thus, results are presented across all combinations. The $T_{50}$ for doveweed treated with atrazine averaged 3.5 DAT following soil-only and foliar + soil applications (Figure 1; Table 1). These treatments injured doveweed faster than atrazine applied to foliage only $\left(T_{50}=4.4 \mathrm{DAT}\right)$. The response of doveweed to simazine was slower than atrazine regardless of application placement. The $T_{50}$ averaged 8 DAT when simazine was applied soil or foliar + soil. Foliar-only treatments of simazine were less injurious than other placements and required $12.2 \mathrm{~d}$ to injure doveweed $50 \%$.

Herbicide by placement interactions were detected for visual injury and shoot mass reduction from the nontreated; thus, results are presented across all combinations. By 16 DAT, atrazine applied foliaronly, soil-only, and foliar + soil caused 99, 100, and $100 \%$ doveweed injury, respectively. Simazine

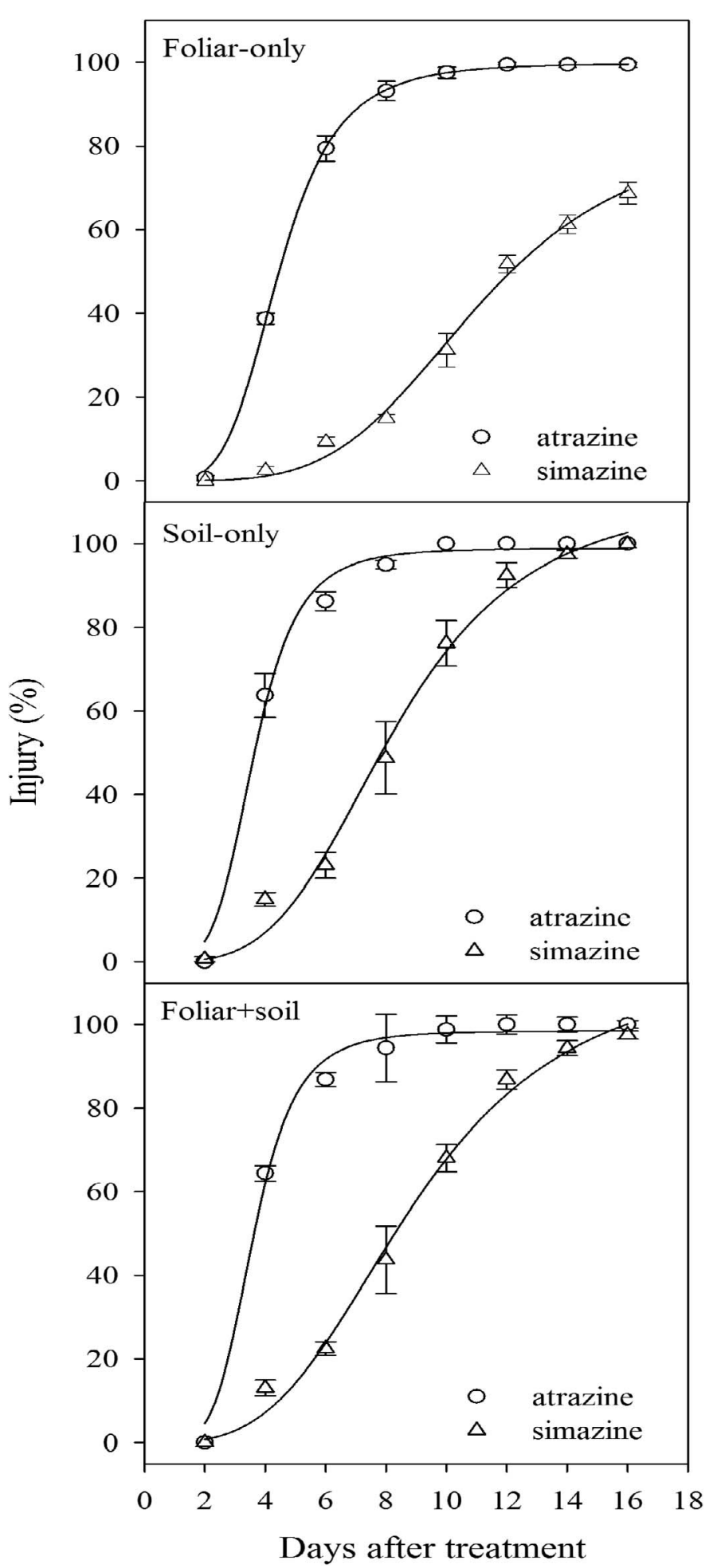

Figure 1. Doveweed injury after atrazine and simazine treatments at three application placements in greenhouse experiments, Griffin, GA. Results were pooled over experimental runs. Vertical bars represent standard errors $(n=8)$.

applied foliar-only injured doveweed 69\%, whereas soil-only and foliar + soil treatments injured doveweed $\geq 97 \%$ (Table 2). By 16 DAT, doveweed biomass was equally reduced from all atrazine placements by $96 \%$ from the nontreated (Table 
Table 1. Time required to cause $50 \%$ doveweed injury $\left(T_{50}\right)$ after foliar, soil, and foliar + soil application of atrazine and simazine in greenhouse experiments, Griffin, GA.

\begin{tabular}{lllrr}
\hline Herbicide & Soil placement & \multicolumn{1}{c}{ Regression equation $^{\mathrm{b}}$} & $T_{50}(\mathrm{days})$ & $95 \% \mathrm{CI}^{\mathrm{c}}$ for $T_{50}$ \\
\hline Atrazine & Foliar-only & $y=99.83 /\left[1+(x / 4.43)^{-4.57}\right]$ & 4.4 & $4.3-4.5$ \\
& Soil-only & $y=98.91 /\left[1+(x / 3.63)^{-4.97}\right]$ & 3.6 & $3.2-3.9$ \\
& Foliar + soil & $y=98.48 /\left[1+(x / 3.60)^{-5.11}\right]$ & 3.5 & $1.2-3.9$ \\
Simazine & Foliar-only & $y=84.04 /\left[1+\left(x / 11.06_{\mathrm{o}}\right)^{-4.23}\right]$ & 7.8 & $7.2-8.5$ \\
& Soil-only & $y=111.78 /\left[1+(x / 8.31)^{-3.69}\right]$ & 8.3 & $7.7-8.8$ \\
& Foliar + soil & $y=114.25 /\left[1+(x / 8.92)^{-3.35}\right]$ & &
\end{tabular}

${ }^{a}$ Atrazine and simazine applied at $1.12 \mathrm{~kg}$ ai ha ${ }^{-1}$.

${ }^{\mathrm{b}}$ In regression equations, $y$ is doveweed injury, and $x$ is days after treatment.

c Abbreviation: CI, confidence interval.

2). Simazine reduced biomass less than atrazine regardless of application placement. Doveweed biomass was reduced $77 \%$ from simazine applied to soil or foliar + soil at 16 DAT. Foliar-only treatments of simazine reduced biomass 51\% and were less effective than other placements.

Doveweed was more responsive to atrazine and simazine treatments that included soil placements compared with foliar-only applications. These results are comparable to previous research that demonstrated significant root uptake potential of these herbicides by susceptible species (Orwick et al. 1976; Shimabukro and Linck 1967). However, application placement had less influence on the efficacy of atrazine than simazine, suggesting foliar penetration may enhance the speed of control. Doveweed, and related species, have limited foliar uptake potential of POST herbicides because of leaf

Table 2. Doveweed injury and shoot mass reduction at $16 \mathrm{~d}$ after foliar, soil, and foliar + soil application of atrazine and simazine in greenhouse experiments, Griffin, GA. Results were pooled over experimental runs.

\begin{tabular}{llcc}
\hline Herbicide & Soil placement $^{\mathrm{a}}$ & Injury & Shoot mass reduction \\
\hline \multirow{4}{*}{ Atrazine } & $\%$ & \% from nontreated \\
& Foliar-only & 99 & 98 \\
& Soil-only & 100 & 96 \\
& Foliar + soil & 100 & 95 \\
Simazine & Foliar-only & 69 & 51 \\
& Soil-only & 100 & 78 \\
& Foliar + soil & 97 & 75 \\
& LSD b.05 & 3 & 10 \\
& Herbicide & $*$ & $*$ \\
& Soil placement & $*$ & $*$ \\
& Herbicide $\times$ & & $*$
\end{tabular}

\footnotetext{
${ }^{\mathrm{a}}$ Atrazine and simazine applied at $1.12 \mathrm{~kg}$ ai ha ${ }^{-1}$.

${ }^{\mathrm{b}}$ Means were separated with Fisher's protected LSD test at the 0.05 probability level.

* Significant at $\mathrm{P}<0.05$ probability level.
}

cuticle thickness (Atkinson 2014; Monquero et al. 2004). Spray retention, volatility, or subsequent movement to soil after irrigation could also influence the penetration of triazine herbicides in doveweed. By 16 DAT, only foliar-only treatments of simazine failed to control doveweed, suggesting that turfgrass managers will likely maximize efficacy of simazine when treatments are applied to soil. Turfgrass managers will likely need to provide irrigation immediately after simazine applications to maximize soil incorporation.

In application rate experiments, atrazine and simazine initially injured doveweed $50 \%$ at 4 and 10 DAT, respectively (Figure 2; Table 3). Atrazine required $\leq 1.8 \mathrm{~kg} \mathrm{ha}^{-1}$ to injure doveweed $50 \%$ from 8 to 16 DAT. Contrarily, the $I_{50}$ from simazine measured $5.1 \mathrm{~kg} \mathrm{ha}^{-1}$ at 16 DAT. The $\mathrm{SR}_{50}$ from atrazine and simazine measured 1.6 and $7.5 \mathrm{~kg} \mathrm{ha}^{-1}$ at 16 DAT, respectively (Table 3; Figure 3). The rapid activity of atrazine is similar to previous reports on oat (Avena sativa L.), giant foxtail (Setaria faberi Herm.), and soybean (Shimabukro and Linck 1967; Thompson and Slife 1969; Vostral et al. 1970). Orwick et al. (1976) reported that simazine absorption and subsequent entry to symplast tissues in Setaria roots occurred through an energy-dependent process that was not detected for atrazine. Perhaps greater uptake potential of atrazine in weeds, such as doveweed, may result in faster control than simazine. The uptake and fate of atrazine and simazine in doveweed could also explain the differential tolerance levels to these herbicides and was further investigated in laboratory experiments.

Laboratory Experiments. Harvest by herbicide interactions were not detected for absorption. Doveweed absorbed both herbicides similarly and averaged $62 \%( \pm 2)$ of the applied radioactivity across all harvests (data not shown). Differences in 


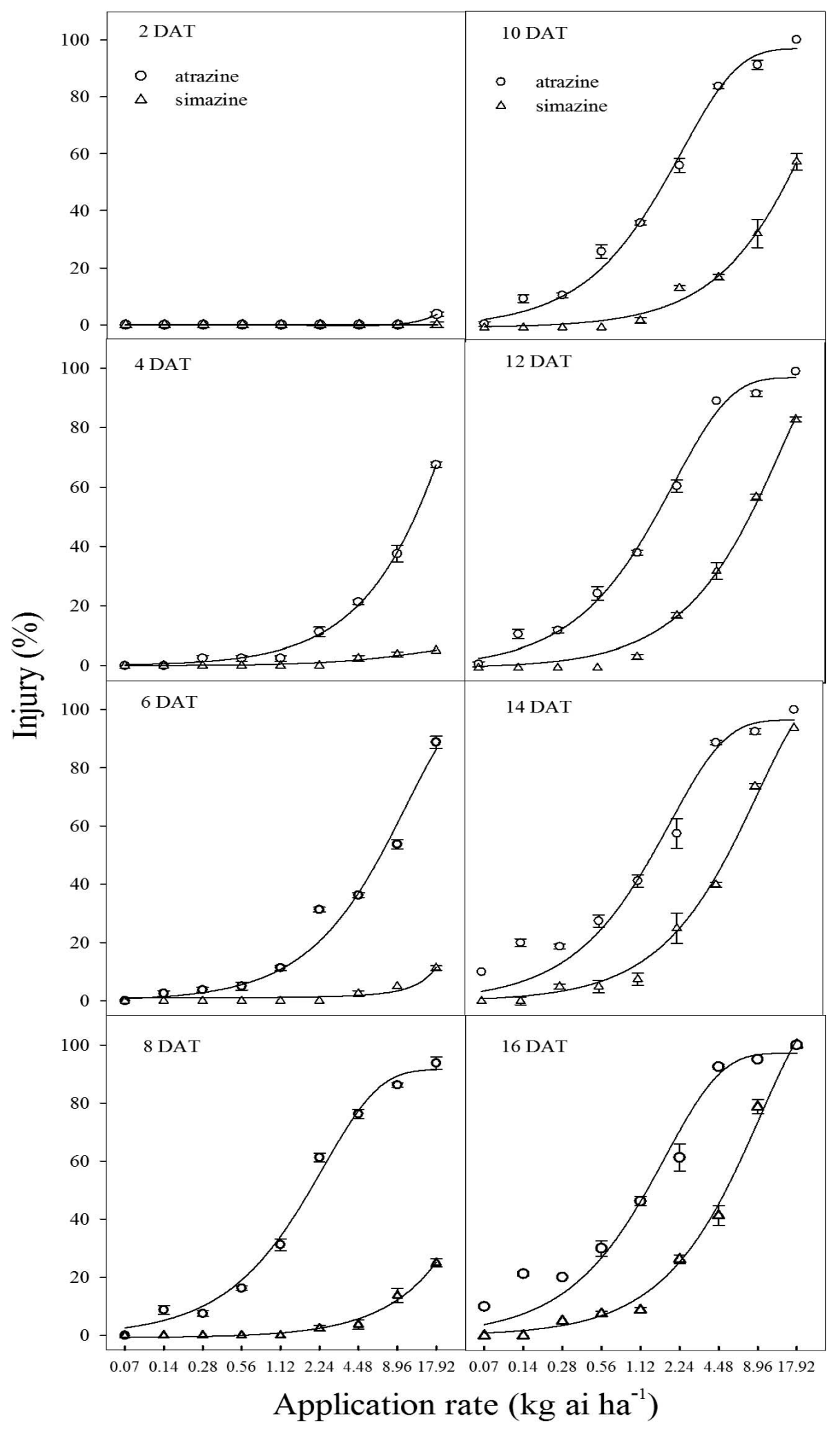

Figure 2. Doveweed injury after atrazine and simazine treatments at 10 rates in greenhouse experiments, Griffin, GA. Results were pooled over experimental runs. Vertical bars represent standard errors $(n=8)$. Abbreviation: DAT, days after treatment.

absorption were not detected across harvest timings. Results indicate that doveweed had similar root uptake of atrazine and simazine after $1 \mathrm{~d}$ before returning to the herbicide-free, hydroponic tank.
Harvest by herbicide interactions were not detected for doveweed metabolism; thus, results were pooled over main effects. From residue oxidation, extraction efficiency of radioactivity 
Table 3. Regression equations and estimates for $50 \%$ doveweed injury $\left(I_{50}\right)$ and $50 \%$ shoot mass reductions $\left(\mathrm{SR}_{50}\right)$ after atrazine and simazine applications in two combined greenhouse experiments, Griffin, GA. ${ }^{\text {a }}$

\begin{tabular}{|c|c|c|c|c|c|}
\hline Measurement & Herbicide & DAT & Regression equation $^{b}$ & $I_{50}$ & $95 \% \mathrm{CI}$ for $I_{50}$ \\
\hline & & & & $\mathrm{kg}$ ai ha ${ }^{-1}$ & \\
\hline \multirow[t]{10}{*}{ Injury } & Atrazine & 2 & $y=1.003 e^{+4}\left[1-\exp \left(-1.564 e^{-5} x\right)\right]$ & $>17.92$ & - \\
\hline & & 6 & $y=104.45[1-\exp (-0.0972 x)]$ & 6.7 & $5.5-8.0$ \\
\hline & & 8 & $y=91.50[1-\exp (-0.4169 x)]$ & 1.8 & $1.6-2.1$ \\
\hline & & 10 & $y=96.88[1-\exp (-0.4260 x)]$ & 1.7 & $1.4-1.9$ \\
\hline & & 16 & $y=97.21[1-\exp (-0.5756 x)]$ & 1.2 & $0.9-1.5$ \\
\hline & Simazine & 2 & $y=6.488 e^{+3}\left[1-\exp \left(-1.612 e^{-5} x\right)\right]$ & $>17.92$ & - \\
\hline & & 4 & $y=7.200 e^{+0}\left[1-\exp \left(-7.048 e^{-2} x\right)\right]$ & $>17.92$ & - \\
\hline & & 6 & $y=7.123 e^{+3}\left[1-\exp \left(-8.451 e^{-5} x\right)\right]$ & $>17.92$ & - \\
\hline & & 8 & $y=8.565 e^{+3}\left[1-\exp \left(-1.619 e^{-4} x\right)\right]$ & $>17.92$ & - \\
\hline & & & & $\mathrm{SR}_{50}$ & $95 \%$ CL for $\mathrm{SR}_{50}$ \\
\hline
\end{tabular}

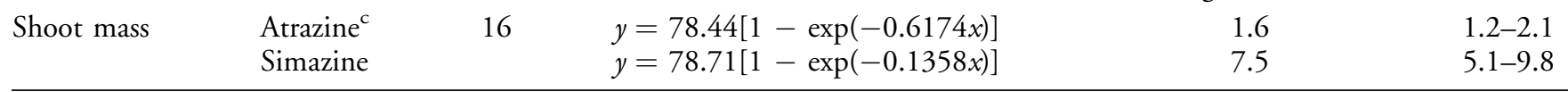

${ }^{a}$ Abbreviations: DAT, days after treatment; CI, confidence interval; CL, confidence limit.

${ }^{\mathrm{b}}$ For regression equations, $y$ is percent doveweed injury or shoot mass reduction from the nontreated, and $x$ is herbicide rate.

${ }^{c}$ Atrazine, 6-chloro-4- $N$-ethyl-2- $N$-propan-2-yl-1,3,5-triazine-2,4-diamine.

averaged $91 \%$ [ \pm 1 standard error of the mean $(\mathrm{SEM})]$ and $87 \%( \pm 1)$ from ${ }^{14} \mathrm{C}$-atrazine and ${ }^{14} \mathrm{C}$ simazine treatments, respectively. Doveweed metabolized ${ }^{14} \mathrm{C}$-atrazine into one primary metabolite at $R_{f} 0.05$ that was identified as hydroxyatrazine (Figure 4). Another metabolite of atrazine was detected at $\mathrm{R}_{\mathrm{f}} 0.5$ but averaged $<10 \%$ of the extracted radioactivity at all harvests. Doveweed metabolized ${ }^{14} \mathrm{C}$-simazine to three major metabolites on all dates. These metabolites were identified at $\mathrm{R}_{\mathrm{f}} 0.05,0.4$, and 0.56 and averaged $29 \%$ ( \pm 1.5 SEM), 22\% ( \pm 2.9$)$, and $24 \%( \pm 1.6)$ of the ${ }^{14} \mathrm{C}$ extracted, respectively. The simazine metabolite at $\mathrm{R}_{\mathrm{f}} 0.05$ was identified as hydroxysimazine, whereas the other two metabolites were unidentified. Doveweed metabolism of both herbicides increased linearly over time and measured 51, 69, and 84\% of the total ${ }^{14} \mathrm{C}$ extracted at 1,3 , and 7 DAT, respectively (Table 4). However, doveweed metabolized less atrazine than simazine, and parent herbicide levels averaged 39 and 25\%, respectively.

Metabolism is the physiological basis for tolerance to triazine herbicides in corn (Zea mays L.), cotton (Gossypium hirsutum L.), grain sorghum [Sorghum bicolor (L.) Moench ssp. bicolor], and various weed species (Davis et al. 1965; De Prado et al., 1995; Jachetta and Radosevich, 1981; Montgomery and Freed, 1961; Roeth and Lavy 1971; Sheets, 1961). The slower metabolism of atrazine than simazine by doveweed supports the supposition that metabolism rate contributes to efficacy. These results are similar to previous research on the differential tolerance levels of giant reed (Arundo donax L.) to atrazine and simazine. Thompson (1972) reported that giant reed metabolized atrazine faster than simazine after $24 \mathrm{~h}$. Although simazine was more injurious to giant reed than atrazine, the role of herbicide metabolism to polar conjugates explained differences in selectivity. Robinson and Greene (1976) reported that a susceptible species to atrazine, witchgrass (Panicum capillare L.), had less metabolism than a more tolerant species, large crabgrass [Digitaria sanguinalis (L.) Scop.]. Enhanced metabolism rate has also conferred resistance of atrazine-resistant biotypes of various foxtail species (Setaria spp.) (De Prado et al. 2000).

Doveweed produced three major polar conjugates of simazine, whereas only one major metabolite was detected for atrazine. The extent of degradation of these herbicides may also indicate the ability of doveweed to detoxify simazine more effectively than atrazine. In other species, Khan et al. (1985) found 


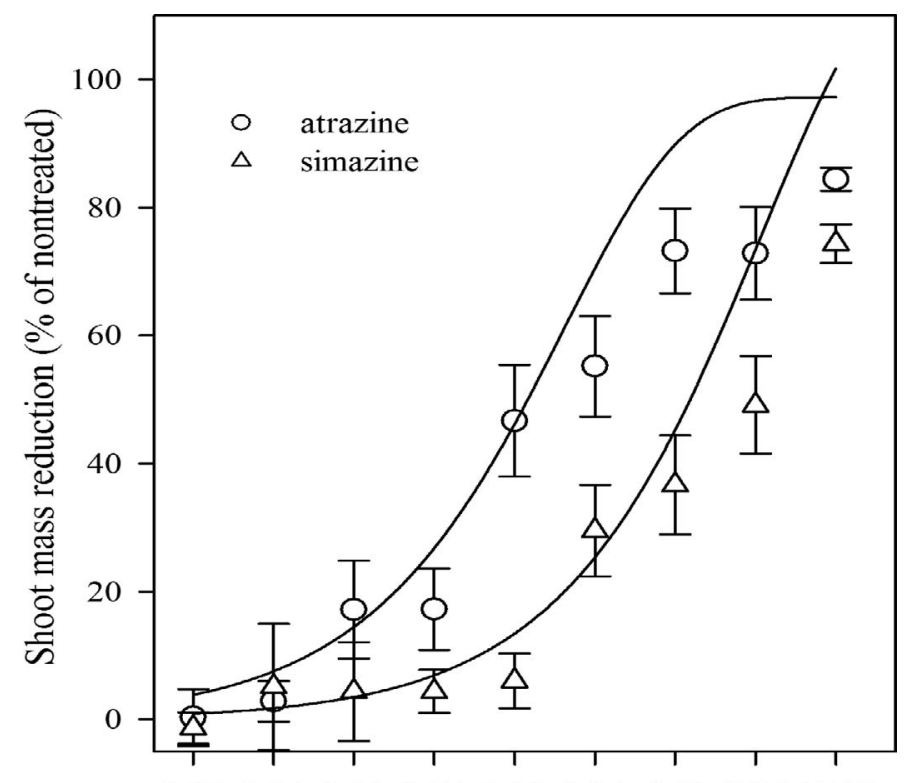

$\begin{array}{lllllllll}0.07 & 0.14 & 0.28 & 0.56 & 1.12 & 2.24 & 4.48 & 8.96 & 17.92\end{array}$

Application rate $\left(\mathrm{kg}\right.$ ai ha $\left.{ }^{-1}\right)$

Figure 3. Doveweed shoot mass reduction at 16 days after treatment in greenhouse experiments, Griffin, GA. Results were pooled over experimental runs. Vertical bars represent standard errors $(n=8)$.

that parent atrazine levels were similar in resistant and susceptible biotypes of common lambsquarters (Chenopodium album L.), lateflowering goosefoot [Chenopodium album var. striatum (Krasan)], and Powell amaranth [Amaranthus powellii S. Wats]. However, the resistant biotypes in each species contained more conjugates than susceptible biotypes.

The interaction of soil activity and plant metabolism could influence efficacy of triazine herbicides, especially for doveweed control in the southern United States. Our results prove that doveweed absorbs atrazine and simazine similarly in hydroponic culture after $24 \mathrm{~h}$. Price and Balke (1982) reported that the initial uptake of ${ }^{14} \mathrm{C}$ atrazine was comparable in species with various tolerance levels, but susceptible species had greater long-term accumulation of the herbicide. Vostral et al. (1970) reported that atrazine uptake in soybean was enhanced by increasing temperature of the root system. The influence of soil $\mathrm{pH}$, degradation, and temperature could influence the availability of atrazine and simazine for doveweed control (Walker and Thompson 2006). Doveweed is adapted to a wide range of $\mathrm{pH}$ levels (Atkinson 2014), and soil degradation could reduce the efficacy of simazine more than atrazine because of slower initial phytotoxicity.

Turfgrass cultural practices could also influence the growth of doveweed and efficacy of herbicides for control. Atkinson (2014) reported that the spread of doveweed was exacerbated in bermudagrass when the mowing height was reduced from 8 to $2 \mathrm{~cm}$. It was also noted that doveweed growth was significantly inhibited when soil moisture was reduced to $<50 \%$ field capacity (FC) compared with levels $\geq 75 \%$ FC. Further research is needed
1 DAT

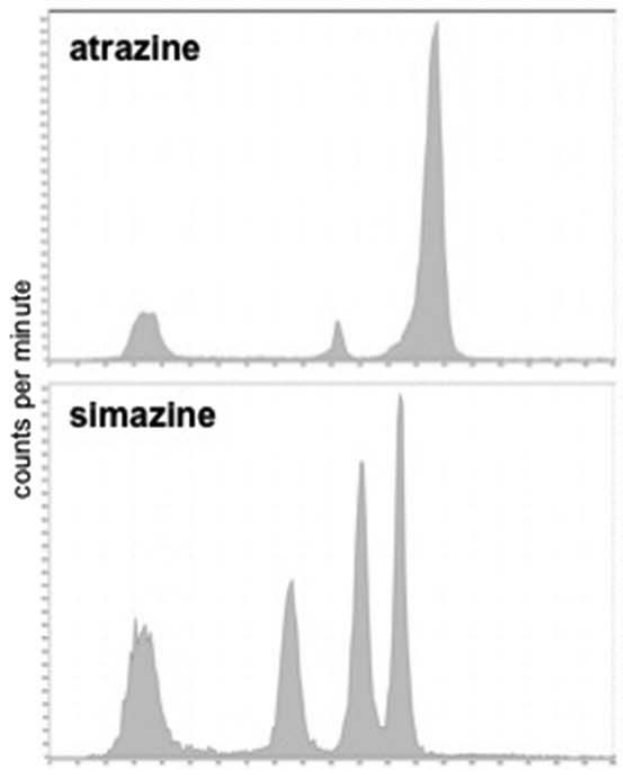

3 DAT

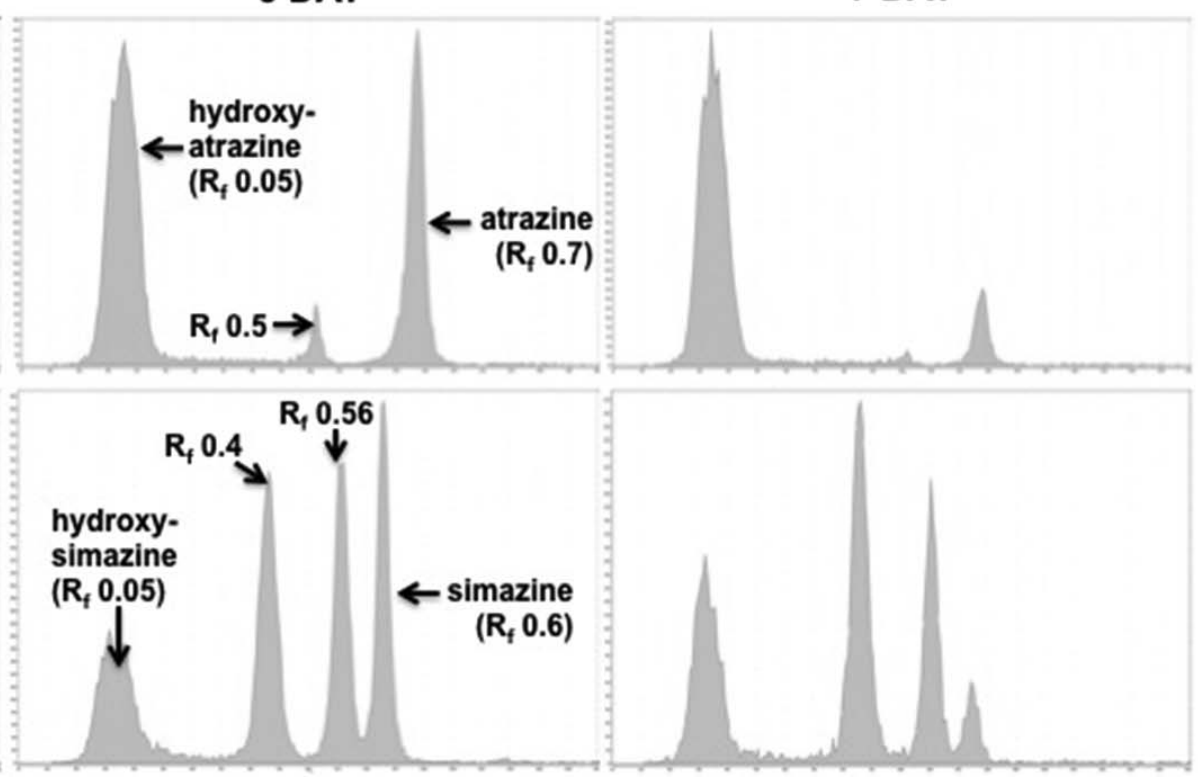

Figure 4. Radiochromatogram scans for doveweed metabolism of ${ }^{14}$ C-atrazine and ${ }^{14} \mathrm{C}$-simazine at 1,3 , and $7 \mathrm{~d}$ after treatment (DAT) in laboratory experiments. 
Table 4. Doveweed metabolism of atrazine and simazine in two experiments, Griffin, GA. Results were pooled over experimental runs.

\begin{tabular}{lc}
\hline Herbicide & Parent herbicide \\
\hline & $\%$ of ${ }^{14} \mathrm{C}$ extracted \\
Atrazine & 39 \\
Simazine & 25 \\
LSD $_{0.05}(\mathrm{DAT})^{\mathrm{a}}$ & 6 \\
Harvest $_{1}$ & \\
$\quad$ & 49 \\
3 & 31 \\
7 & 16 \\
LSD $_{0.05}$ & 7 \\
Linear & $*$ \\
Quadratic & $\mathrm{NS}$ \\
Herbicide & $*$ \\
Harvest & $*$ \\
Herbicide $\times$ harvest & $\mathrm{NS}$ \\
\hline
\end{tabular}

${ }^{a}$ Abbreviation: DAT, days after treatment.

to evaluate management practices, such as mowing and irrigation, on the efficacy of triazine herbicides for doveweed control.

Doveweed is a problematic weed in turfgrass throughout the southeastern United States. Turfgrass managers often apply herbicides sequentially to increase efficacy and incorporate various modes of action for control. Atrazine has faster activity than simazine on doveweed but might also temporarily injure turfgrasses, such as bermudagrass (McCarty 1996). Simazine has significant efficacy on doveweed when soil incorporation is not precluded. Atrazine requires lower rates and is less dependent on soil applications than simazine. The efficacy of triazines on doveweed is related to degradation rate and the extent of metabolism. Doveweed is more susceptible to atrazine because of slower metabolism and fewer conjugates produced than simazine.

\section{Acknowledgments}

The authors thank Seth Williams, Brad Konwick, Dr. Sudeep Sidhu, and VJ Mantripragada for technical support with this research.

\section{Literature Cited}

Anonymous (2008) Banvel ${ }^{\circledR}$ herbicide label. Cary, NC: Arysta LifeScience North America

Anonymous (2010a) Specticle ${ }^{\circledR}$ herbicide Label. Research Triangle Park, NC: Bayer CropScience

Anonymous (2010b) 2,4-D Amine ${ }^{\circledR}$ herbicide Label. St. Paul, MN: Winfield Solutions LLC
Atkinson J (2014) Biology, Ecology, and Control of Doveweed (Murdannia nudiflora [L.] Brenan). Ph.D dissertation. Clemson, SC: Clemson University. Pp 38-50, 60-88

Chachalis D, Reddy KN, Elmore CD, Steele ML (2001) Herbicide efficacy, leaf structure, and spray droplet contact angle among Ipomoea species and smallflower morningglory. Weed Sci 49:628-634.

Chauhan BS, Abugho SB (2013) Weed management in mechanized-sown, zero-till dry-seeded rice. Weed Technol 27:28-33

Davis DE, Gramlich JV, Funderburk HH (1965) Atrazineabsorption and degradation by corn, cotton, and soybeans. Weeds 13:252-255

De Prado R, Lopez-Martinez N, Gonzalez-Gutierrez J (2000) Identification of two mechanisms of atrazine resistance in Setaria faberi and Seteria viridis biotypes. Pestic Biochem Physiol 67:114-124

De Prado R, Romera F, Menedez J (1995) Atrazine detoxification in Panicum dichotomiflorum and target site Polygonum lapathifolium. Pestic Biochem Physiol 52:1-11

Graham JC, Buchholtz KP (1968) Alteration of transpiration and dry matter with atrazine. Weed Sci 16:389-392

Hoagland DR, Arnon DI (1950) The Water-Culture Method for Growing Plants without Soil. Cir 347. Berkley, CA: University of California Agricultural Experiment Station

Jachetta JJ, Radosevich SR (1981) Enhanced degradation of atrazine by corn (Zea mays). Weed Sci 29:37-44

Johnson BJ (1973) Establishment of centipedegrass and St. Augustine grass with the aid of chemicals. Agron J 65:959-962

Johnson BJ (1979) Bahiagrass (Paspalum notatum) and common lespedeza (Lespedeza striata) control with herbicides in centipedegrass (Eremochloa ophiuroides). Weed Sci 27:346348.

Khan SU, Warwick SI, Marriage PB (1985) Atrazine metabolism in resistant and susceptible biotypes of Chenopodium album L., Chenopodium strictum Roth., and Amaranthus powellii S. Wats. Weed Res 25:33-37

McCarty LB (1996) Selective control of common bermudagrass in St. Augustinegrass. Crop Sci 36:694-698

Monquero PA, Christoffoleti PJ, Matas JA, Heredia A (2004) Leaf surface characterization and epicuticular wax composition in Commelina benghalensis, Ipomoea grandifolia, and Amaranthus hybridus. Planta Daninha 22:203-210

Montgomery M, Freed VH (1961) The uptake, translocation, and metabolism of simazine and atrazine by corn plants. Weeds 9:231-237

Orwick PL, Schreiber MM, Hodges TK (1976) Absorption and efflux of chloro-s-triazines by Setaria roots. Weed Res 16:139144

Price TP, Balke NE (1982) Characterization of rapid atrazine absorption by excised velvetleaf (Abutilon theopbrasti) roots. Weed Sci 30:633-639

Robinson DE, Greene, DW (1976) Metabolism and differential susceptibility of crabgrass and witchgrass to simazine and atrazine. Weed Sci 24:500-504

Roeth FW, Lavy TL (1971) Atrazine, translocation, and metabolism in sudangrass, sorghum, and corn. Weed Sci 19:98-101

Sanyal D, Bhowmik PC, Reddy KN (2006) Influence of leaf surface micromorphology, wax content, and surfactant on primisulfuron droplet spread on barnyardgrass (Echinochloa crus-galli) and green foxtail (Setaria viridis). Weed Sci 54:627633 
Sheets TJ (1961) Uptake and distribution of simazine by oat and cotton seedlings. Weeds 9:1-13

Shimabukro RH, Linck AJ (1967) Root absorption and translocation of atrazine in oats. Weeds 15:175-178

Thompson L (1972) Metabolism of simazine and atrazine by wild cane. Weed Sci 20:153-155

Thompson L, Slife FW (1969) Foliar and root absorption of atrazine applied postemergence to giant foxtail. Weed Sci $17: 251-256$

Ulloa SM, Owen MD (2009) Response of Asiatic dayflower (Commelina communis) to glyphosate and alternatives in soybean. Weed Sci 57:74-80

Vostral HJ, Buchholtz KP, Kust CA (1970) Effect of root temperature on absorption and translocation of atrazine in soybeans. Weed Sci 18:115-117

Walker A, Thompson JA (2006) The degradation of simazine, linuron, and propyzamide in different soils. Weed Res $17: 399-405$
Walker LC, Neal JC, Derr JE (2010) Preemergence control of doveweed (Murdannia nurdiflora) in container-grown nursery crops. J Environ Hortic 28:8-12

Wanamarta G, Penner D (1989) Foliar absorption of herbicides. Rev Weed Sci 4:215-231

Wilson DG, Burton MG, Spears JF, York AC (2006) Doveweed (Murdannia nudiflora) germination and emergence as affected by temperature and seed burial depth. Weed Sci 54:10001003

Received October 18, 2015, and approved January 21, 2016.

Associate Editor for this paper: Steven Seefeldt, University of Alaska at Fairbanks. 